Jurnal Ekonomi Syariah Teori dan Terapan p-ISSN: 2407-1935, e-ISSN: 2502-1508. Vol. 7 No. 8 Agustus 2020: 1572-1583; DOI: 10.20473/vol7iss20208pp1572-1583

\title{
THE RELATIONSHIP BETWEEN EMPLOYER BRANDING, CORPORATE REPUTATION, AND RECRUITMENT WEB ON INTENTION TO APPLY ${ }^{1}$
}

\author{
Fenti Erlinda, Rini Safitri \\ Faculty of Economics, State Islamic University Maulana Malik Ibrahim Malang \\ fentierlinda48@gmail.com*, rini.safitri@uin-malang.ac.id
}

\begin{abstract}
ABSTRAK
Penelitian tentang minat melamar kerja sudah banyak dilakukan sebelumnya. Beberapa penelitian tersebut menghasilkan bahwa variabel-variabel yang berpengaruh terhadap minat melamar kerja adalah employer branding, reputasi perusahaan, website recruitment, akan tetapi dalam hasil penelitian tersebut terdapat ketimpangan yang menyebutkan bahwa reputasi perusahaan dan website recruitment tidak berpengaruh terhadap minat melamar kerja, sehingga perlu dilakukan penelitian kembali untuk menjawab rumusan masalah terkait dengan pengaruh employer branding, reputasi perusahaan dan website recruitment terhadap minat melamar kerja. Tujuan penelitian ini adalah untuk mengetahui pengaruh employer branding, reputasi perusahaan, dan website recruitment terhadap minat melamar kerja. Populasi pada subjek penelitian sebanyak 102,290 orang dengan sampel responden sebanyak 99 orang. Metode penentuan sampel menggunakan metode simple random sampling. Pengumpulan data pada penelitian ini dilakukan melalui observasi, wawancara, dan kuesioner. Pendekatan yang digunakan dalam penelitian ini adalah pendekatan kuantitatif, pengujian hipotesis dalam penelitian ini menggunakan Partial Least Square (PLS) versi 3.2.9. Hasil penelitian menunjukkan employer branding dan reputasi perusahaan memiliki pengaruh positif dan signifikan terhadap minat melamar kerja, sedangkan website recruitment memiliki pengaruh negatif dan signifikan terhadap minat melamar kerja.
\end{abstract}

Kata Kunci: employer branding, reputasi perusahaan, website recruitment, minat melamar kerja

\author{
Informasi artikel \\ Diterima: 10-06-2020 \\ Direview: 20-08-2020 \\ Diterbitkan: 25-08-2020 \\ ${ }^{*}$ Korespondensi \\ (Correspondence): \\ Fenti Erlinda \\ Open access under Creative \\ Commons Attribution-Non \\ Commercial-Share A like 4.0 \\ International Licence \\ (CC-BY-NC-SA) (c) (†)
} ABSTRACT
Research on intention to apply has been done before.
Some of the research that resulted in that the variables - variables
that influence on intention to apply is employer branding,
reputation of the company, the website recruitment, will be but
the results of the study are contained inaccuracies which said that
the reputation of the company and website recruitment no effect
on intention to apply, so it needs to do research back to answer
the formulation of the problems associated with the effect of
employer branding, reputation of the company and website
recruitment against intention to apply. The purpose of this study
was to determine the effect of employer branding, company
reputation, and website recruitment on intention to apply. The
population in the study subjects was 102,290 people with a sample
of respondents as many as 99 people. The method of determining

\footnotetext{
${ }^{1}$ Artikel ini merupakan bagian dari skripsi dari Fenti Erlinda, NIM: 16540082, yang berjudul, "Pengaruh Employer Branding, Reputasi Perusahaan, dan Website Recruitment Terhadap Minat Melamar Kerja Bank Syariah Mandiri Pada Mahasiswa Perguruan Tinggi Negeri Kota Malang."
} 
the sample using simple random sampling method. Data collection in this study was carried out through observation, interviews, and questionnaires. The approach that is used in research this is the approach of quantitative, testing the hypothesis in research is using Partial Least Square (PLS) version 3.2.9. Results of the study show the employer branding and reputation of the company has influence positively and significantly to intention to apply, while the website recruitment has influence negatively and significantly against intention to apply.

\section{Keywords: employer branding, company reputation, website recruitment, intention to apply}

\section{INTRODUCTION}

\section{Background}

Potential employees are the most valuable asset any company can have (Fishman, 1998). They need to formulate a strategy in order to keep their job appealing, so those potential employees will be interested to apply. For financial institution, one of such strategy is called employer branding, a method where the employer promote their brand not only to customer, but also to their human resource. Ferizal (2016) stated that employer branding is a method that is used to create distinction about company, which makes their offered jobs and values standout compared to their competitors. An effective employer branding will increase employees' loyalty and contribute to growing interest in jobs offered by the company, where it will more likely to be chosen by potential employees (Highthouse et al, 2003).

Reputation of the financial institution is also a concern for people who are looking for jobs. Fomburn (1996) explained that reputation is a tool that can be used to predict the interest of potential employees to work at financial institution. Reputation is an intangible asset for financial institution, and thus, will affect the assessment of potential employees. If the reputation is good, it will be easier for the institution to attract more of those potential employees to work for them.

If potential employees chose to work in particular institution, then the next step is to recruit them. Recruitment is a method to choose, gain, and attract new employees to work in the company (Sutrisno, 2012). Collins and Stevens (2002) advised that organization should always devise a strategy to recruit new employees, so they will always get the best result. The most appropriate strategy in recruitment is to provide complete informations about organization. With such informations, potential employees will be able to understand organization and their recruitment method more effectively, even if they use website recruitment (Rynes and Cable, 2003).

Previous researches indicated that the impact of employer branding on intention to apply is significant positive (Santiago, 2019; Sharma and Prasad, 2018; Arasanmi and Krishna, 2018; Agrawal and Swaroop, 2009.) Another research 
regarding how company reputation affect intention to apply were carried out by some authors (Saini et al., 2016; Chabbara and Sharma, 2016; Yu and Davis, 2016; Xie et al., 2016; Cable and Turban, 2004; Cannaby, 2018; Sumardana et al., 2014; Permadi and Netra, 2016; Fajrina, 2015). Their findings showed that company reputation had significant positive impact on intention to apply. Some past research also conducted about website recruitment, where it had positive significant effect on intention to apply (Lyons dan Marler, 2016; Allen et al., 2017; Fridantara and Muafi, 2018; Mochi et al., 2017; Baum and Kabst, 2014; Lepak et al., 2003; Allen et al., 2013; Cober et al., 2004; Walker et al., 2011; Cable and Turban, 2003; Williamson et al., 2010; Braddy et al., 2006; Matthias and Rudiger, 2014.) While these past researches yielded positive result among all mentioned variables, some showed direct opposite. Gupta and Saini showed in their research that reputation did not have any effect towards intention to apply and Chapman et al. (2005) stated that there are connection between website recruitment and intention to apply.

Based on past researches, we can see that there are different results about how company reputation and website recruitment can affect intention to apply. These differences create inconsistency between the results, therefore additional research regarding these topics should be done. It should also be noted the research about intention to apply in financial institution such as Syariah Bank were not found among students in Malang City state universities. To address this gap, this article will discuss a research about the impact of employer branding, company reputation, and website recruitment on intention to apply so that this research is feasible to do to anser. the formulation of the problem, approve the influence of employer branding, company reputation , and website recruitment on the interest in applying for work. With the purpose to determine the extent to Which the effect of employer branding, reputation of the company, and the recruitment website of the interest in applying for a job.

\section{Research Objective}

The objectives in this study are:

1. Knowing the extent of the impact of employer branding on the intention to apply

2. Knowing the extent of the impact company's reputation on the intention to apply

3. Knowing the extent of the impact recruitment website on the intention to apply

\section{Research Benefits}

Benefits in this research are:

1. It can expand the treasury of science in the field of economics, especially Islamic banking.

2. It can be used as a medium of information and benchmarks to find out the interests of job seekers in applying for jobs at financial institutions 
3. It helps financial institutions to further increase recruitment of job seekers.

\section{LITERATURE REVIEW AND} HYPOTHESIS

\section{Employer Branding}

According to Rucika and Sharma (2018) employer branding is defined as a functional package, economic allnd psychological benefits provided by the company to its employees, corporate branding can positively influence the company's reputation and can attract job seekers. Meanwhile Livens et al (2007) defines employer branding as a special form of company in managing identity by creating a reputation or company image both communicated and developed internally and externally to company stakeholders.

\section{Company Reputation}

According to Bannet and Rentschler, (2003) Corporate reputation is considered a strategic and valuable resource that can contribute to the competitive advantage of a financial institution. As for forming a good company reputation requires a long process so it is difficult to be imitated by competitors. Meanwhile, according to Fombrun (1996) the company's reputation is interpreted as a picture of financial institutions in the past, including the prospects owned in the future. According to Williamson et al (2010) a company's reputation is a stakeholder assessment of financial institutions if seen through its performance. Based on the explanation above, it can be understood that the company's reputation is an intangible asset owned by the company that has a positive effect on the job seeker's assessment.

\section{Website Recruitment}

Cappeli (2001) website is the main tool used by a company to attract job applicants. On the recruitment website there is complete information about the history of the company, and employment, detailed information about the company can help job seekers find out the characteristics of the company. The recruitment website also offers convenience for communicating, and also accessing unlimited information related to company and job characteristics, information conveyed through several channels, for example: text, images, graphics, audio files or interactive links. This accurate information is communicated to a number of areas and can be accessed by job seekers at a lower cost (Cober et al, 2000).

\section{Intention To Apply}

Barber (1998) intention to apply is a process of interest to join a company that begins by gathering information about the company, then proceed with learning about job openings, and ends with sending job applications to the intended company. When job seekers are interested in working for a company, then actually job seekers have developed positive or negative perceptions about the company and jobs based on information communicated by a company. The job seeker's decision to collect company information is then evaluated based on the ability, knowledge, 
and values contained in the job seeker, identified with the attributes that exist in the company in accordance with organizational needs. Descriptions above showed that there are connections between employer branding, company reputation, and website recruitment toward intention to apply. The conceptual model is presented in Figure 1.

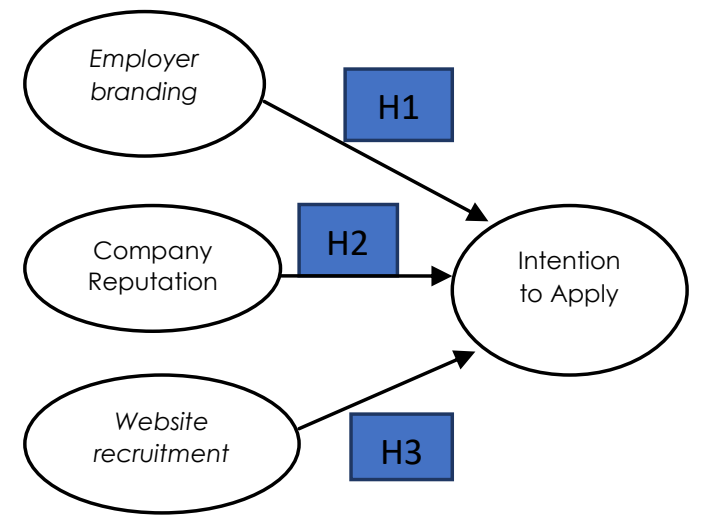

Source: developed from past researches

Figure 1.

Conceptual Model

Explanation:

$\mathrm{Hl}=$ there is influence of employer branding on intention to apply

$\mathrm{H} 2$ = there is influence of company reputation intention to apply

$\mathrm{H} 3=$ there is influence of website recruitment on intention to apply

\section{RESEARCH METHOD}

This research was performed in state universities in Malang City, with all active students acted as population (102,290 people). Sampling method used is simple random sampling, where all member of population have equal chance to become a sample (Sugiyono, 2013). To obtain the appropriate number ofsamples, Slovin formula was used, and 100 respondents were chosen from population pool. In order to collect essential data for research, we used questionnaires. These questionnaires have question items such as "mission of syariah bank is easy to understand". "I am happy with the presence of syariah bank", "it is easy for me to understand the website recruitment", "I will do my best in order to earn my place in syariah bank". Data obtained form those questionnaires were processed to test the proposed hypothesis, using Partial Least Square (PLS) version 3.2.9.

\section{RESULT AND DISCUSSION \\ Characteristics of Respondents}

Characteristics of Respondents in this research are categorized in four group, which is gender, age, education, and marital status. There are 102,290 active students in state universities in Malang City, where 100 of them acted as respondents. Information regarding these respondents is presented in Table 1.

Table 1.

Characteristics of Respondents

\begin{tabular}{|c|c|c|}
\hline Gender & Frequency & Percentage \\
\hline Male & 25 & $25 \%$ \\
\hline Female & 75 & $75 \%$ \\
\hline Total & 100 & $100 \%$ \\
\hline Age & Frequency & Percentage \\
\hline $17-23$ & 100 & $100 \%$ \\
\hline $24-29$ & 0 & $0 \%$ \\
\hline$>34$ years old & 0 & $0 \%$ \\
\hline Total & 100 & 100 \\
\hline Education & Frequency & Percentage \\
\hline S1 (bachelor) & 100 & $100 \%$ \\
\hline S2 (master) & 0 & $0 \%$ \\
\hline s3 (doctoral) & 0 & $0 \%$ \\
\hline Total & 100 & 100 \\
\hline Marital Status & Frequency & Percentage \\
\hline Unmarried & 100 & $100 \%$ \\
\hline Married & 0 & $0 \%$ \\
\hline Total & 0 & $0 \%$ \\
\hline
\end{tabular}

Source : Processed Primary Data, 2020 
Based on gender, there are more female respondents $(75 \%)$ than male respondents (25\%), which shows that there are 75 women and 25 men that was chosen for this research. The ages for all 100 respondents are between 17 to 23 , which shows that all $100 \%$ of them are aged between 17 years old to 23 years old. All of these respondents already has bachelor degree, which shows that $100 \%$ of them have completed their bachelor program in their respective universities. From the marital status, it is shown that $100 \%$ of them (100 people) are unmarried.

\section{Measurement Model (Outer Model) Validity and Reliability Test}

The result for validity and reliability test are presented in Table 2, 3, 4 and 5.

Table 2.

Validity Test Result Employer branding

\begin{tabular}{|c|c|c|c|}
\hline \multirow[t]{2}{*}{ Variabel } & \multicolumn{2}{|c|}{ Result } & \multirow[t]{2}{*}{ Validity } \\
\hline & Item & $\begin{array}{l}\text { Loading } \\
\text { Factor }\end{array}$ & \\
\hline \multirow{11}{*}{$\begin{array}{l}\text { Employer } \\
\text { Branding } \\
\text { (EB) }\end{array}$} & EB.1.1 & 2.309 & Valid \\
\hline & EB.1.2 & 17.084 & Valid \\
\hline & EB.1.3 & 4.786 & Valid \\
\hline & EB.2.1 & 2.990 & Valid \\
\hline & EB.2.2 & 3.823 & Valid \\
\hline & EB.2.3 & 8.846 & Valid \\
\hline & EB.2.4 & 2.494 & Valid \\
\hline & EB.3.1 & 4.192 & Valid \\
\hline & EB.3.2 & 2.659 & Valid \\
\hline & EB.3.3 & 2.811 & Valid \\
\hline & EB.3.4 & 0.636 & Valid \\
\hline
\end{tabular}

Source: Results from SmartPLS Version 3.2.9

Table 3.

Validity Test Result Company Reputation

\begin{tabular}{|c|c|c|c|}
\hline Variabel & \multicolumn{2}{|c|}{ Result } & Validity \\
\hline & Item & $\begin{array}{l}\text { Loading } \\
\text { Factor }\end{array}$ & \\
\hline \multirow{13}{*}{$\begin{array}{l}\text { Company } \\
\text { Reputation } \\
\text { (CR) }\end{array}$} & CR.1.1 & 10.270 & Valid \\
\hline & CR.1.2 & 12.133 & Valid \\
\hline & CR.2.1 & 4.652 & Valid \\
\hline & CR.2.2 & 8.200 & Valid \\
\hline & CR.2.3 & 3.459 & Valid \\
\hline & CR.3.1 & 3.942 & Valid \\
\hline & CR.3.2 & 8.732 & Valid \\
\hline & CR.3.3 & 4.860 & Valid \\
\hline & CR.4.1 & 1.602 & Valid \\
\hline & CR.4.2 & 3.524 & Valid \\
\hline & CR.5.1 & 1.547 & Valid \\
\hline & CR.5.2 & 11.794 & Valid \\
\hline & CR.5.3 & 2.999 & Valid \\
\hline
\end{tabular}

\begin{tabular}{|l|l|l|l|}
\hline & CR.6.1 & 4.264 & Valid \\
\cline { 2 - 4 } & CR.6.2 & 16.862 & Valid \\
\cline { 2 - 4 } & CR.6.3 & 2.284 & Valid \\
\cline { 2 - 4 } & CR.6.4 & 4.297 & Valid \\
\hline
\end{tabular}

Source: Results from SmartPLS Version 3.2.9

Table 4.

Validity Test Result Website Recruitment

\begin{tabular}{|l|l|l|l|}
\hline \multicolumn{1}{|c|}{ Variabel } & \multicolumn{2}{|c|}{ Result } & Validity \\
\hline \multirow{4}{*}{$\begin{array}{l}\text { Website } \\
\text { Recruitment } \\
\text { (WR) }\end{array}$} & Item & $\begin{array}{l}\text { Loading } \\
\text { Factor }\end{array}$ & \\
\cline { 2 - 4 } & WR.1.1 & 3.468 & Valid \\
\cline { 2 - 4 } & WR.1.2 & 3.160 & Valid \\
\cline { 2 - 4 } & WR.1.3 & 4.944 & Valid \\
\cline { 2 - 4 } & WR.1.4 & 7.538 & Valid \\
\cline { 2 - 4 } & WR.2.1 & 6.780 & Valid \\
\cline { 2 - 4 } & WR.2.2 & 10.682 & Valid \\
\cline { 2 - 4 } & WR.2,3 & 5.725 & Valid \\
\cline { 2 - 4 } & WR.2.4 & 3.728 & Valid \\
\hline
\end{tabular}

Source : Results from SmartPLS Version 3.2.9

Table 5.

Validity Test Result Intention to Apply

\begin{tabular}{|c|c|c|c|}
\hline \multirow[t]{2}{*}{ Variabel } & \multicolumn{2}{|c|}{ Result } & \multirow[t]{2}{*}{ Validity } \\
\hline & Item & $\begin{array}{l}\text { Loading } \\
\text { Factor }\end{array}$ & \\
\hline \multirow{5}{*}{$\begin{array}{l}\text { Intention To } \\
\text { Apply (IA) }\end{array}$} & |A.1 & 4,768 & Valid \\
\hline & IA.2 & 12.053 & Valid \\
\hline & IA.3 & 24.550 & Valid \\
\hline & IA.4 & 13.950 & Valid \\
\hline & IA. 5 & 7.370 & Valid \\
\hline
\end{tabular}

Source : Results from SmartPLS Version 3.2.9

Based on validity test result, the value of indicators showed good results, where employer branding has loading factor above 0.5 for all items and fulfilled the criteria for convergent validity. The results for company reputation also showed loading factor value above 0.5 , so this variable has fulfilled the criteria fo convergent validity. Website recruitment has the same results, where it's above 0.5 loading factor indicate that this variable fulfilled the convergent validity criteria. Intention to apply also showed same results, with the value of loading factor $>$ 0.5 and has good convergent validity.

Table 6.

Reliability Test Result

\begin{tabular}{|l|l|l|l|}
\hline Variabel & $\begin{array}{l}\text { Composite } \\
\text { Reliability }\end{array}$ & $\begin{array}{l}\text { Cronbachs } \\
\text { Alpha }\end{array}$ & Result \\
\hline EB & 0,732 & 0,664 & Reliable \\
\hline CR & 0,846 & 0,820 & Reliable \\
\hline
\end{tabular}




\begin{tabular}{|l|l|l|l|}
\hline WR & 0,799 & 0,722 & Reliable \\
\hline IA & 0,823 & 0,728 & Reliable \\
\hline
\end{tabular}

Source : Results from SmartPLS Version 3.2.9

Based on reliability test, it is shown that the value of composite reliability are 0.732 for employer branding (EB), 0.846 for company reputation (CR), 0.799 for website recruitment (WR), and 0.823 for intention to apply (IA). All of these values are above 0.7, which means that all variabels have a good reliability.

\section{Structural Model (Inner Model)}

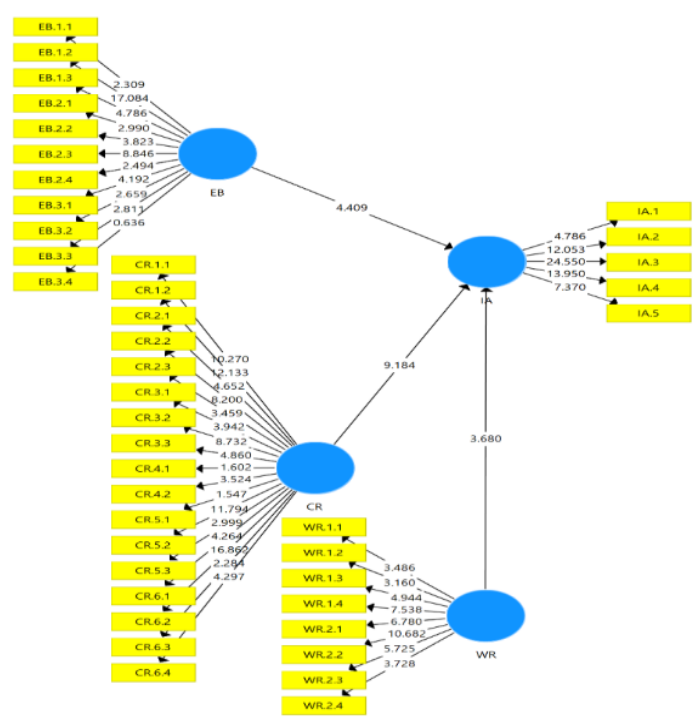

Source : Results from SmartPLS Version 3.2.9

Figure 2

Uji Inner Model

\section{R-Square Calculation}

The first step to evaluate the structural model is to see the value of $\mathrm{R}$ Square in latent dependent variable in the research. Table 4 present the value of $R$ Square for intention to apply.

Table 7.

\begin{tabular}{|c|c|} 
R-Square Value \\
\hline Variable & R-Square \\
\hline Intention to Apply & 0,914 \\
\hline
\end{tabular}
Source : Results from SmartPLS version 3.2.9

Based on Table 7, the result show that R-Square for the variabel intention to apply is $0.914(91.4 \%)$. This result indicates that this variabel can be explained by employer branding, company reputation, and website recruitment by $91,4 \%$. While the rest of $8.6 \%$ are affected by another variabel that is not currently used in this research.

\section{Hypotheses Proposal}

In proposing hypotheses, a t-test was performed. This test was based on the value of path coefficient.

Table 8.

Indirect Correlation Between Variables

\begin{tabular}{|l|l|l|l|l|l|}
\hline & $\begin{array}{l}\text { Origin } \\
\text { al } \\
\text { sampl } \\
\text { e }\end{array}$ & $\begin{array}{l}\text { Averag } \\
\text { e } \\
\text { sample }\end{array}$ & $\begin{array}{l}\text { Standart } \\
\text { deviatio } \\
\mathrm{n}\end{array}$ & $\begin{array}{l}\text { T Statisti } \\
\mathrm{C}\end{array}$ & $\begin{array}{l}\mathrm{P} \\
\text { valu } \\
\mathrm{e}\end{array}$ \\
\hline CR & 0,764 & 0,767 & 0,083 & 9,184 & 0,000 \\
\hline EB & 0,416 & 0,419 & 0,094 & 4,409 & 0,000 \\
\hline $\begin{array}{l}\text { W } \\
\text { R }\end{array}$ & 0,312 & 0,300 & 0,085 & 3,680 & 0,000 \\
\hline
\end{tabular}

Source : Results from SmartPLS Version 3.2.9

The Effect of Employer Branding on

\section{Intention to Apply}

From the research conducted on students of state universities in Malang City. It is shown that employer branding has significant impact on intention to apply in Bank Syariah Mandiri. The path analysis of inner model on employer branding (X1) has significant effect on intention to apply (Y). This is shown by positive coefficient of 0.416 with $p$-values of $0.000<0.050$, so the first hypothesis is accepted. It is indicated that employer branding used by Bank Syariah Mandiri is effective, and thus, give positive and significant result towards intention to apply. This finding correlate with theory from Highthouse et al. (2003) where they stated that an effective employer branding will preserve the loyalty of potential employees and also affect the decision they made. 
The result of this research support findings in previous researches (Arasanmi and Krishna, 2018; Santiago, 2019; Sharma and Prasad, 2018; Agrawal and Swaroop, 2009.) which showed that employer branding can affect intention to apply. It is also indicated by those past researches that a successful employer branding will provide a positive and significant contribution towards intention to apply. Santiago (2019) stated that employer branding should be based on the overall benefit offered by the company to their employees in order to build a unique identity in the eyes of workers and job seekers. By doing so, Bank Syariah Mandiri have provided the best benefit to their worker and develop an appealing image to potential employees through the concept of employer branding.

In Islamic view, it is always advised to do good deeds, especially that which give benefits to others. It is as stated in Al-Quran surah Al-Isra' verse number 7 :

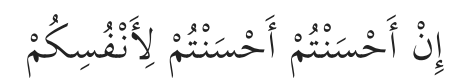

"If you do good, you do good for yourselves" (QS. Al-Isra:7)

Based on that verse, it can be concluded that Bank Syariah Mandiri, as an islamic financial institution had given best benefit to their workers through employer branding, which also create a good image to potential employees who seek job. This is the kind of concept applied by Bank Syariah Mandiri. By utilizing all indicators of employer branding with the intention to bring benefit to their workers, a positive feedback were given by potential employees, where they are willing to apply for a job in Bank Syariah mandiri.

\section{The Effect of Company Reputation on Intention to Apply}

Based on the result of this research, it is shown that company reputation has a significant positive effect on intention to apply in Bank Syariah Mandiri. It is shown by a positive coefficient of 0.764 with $p$ values of 0.000 . The result from loading factor showed the highest result from financial performance, which is 16,682 . These findings indicated that Bank Syariah Mandiri had perform well in attracting new employees, based on their financial performance. This result correlate with the theory from Fombrun (1999), which stated that a good company reputation can be assessed by their financial performance in the past, as well as prospects for the future.

Results from this research also support other previous findings regarding how company reputation can affect intention to appy (Saini et al., 2016; Chabbara and Sharma, 2016; Yu and Davis, 2016; Xie et al., 2016; Cable and Turban, 2004; Sumardana et al., 2014; Permadi and Netra, 2016; Fajrina, 2015.). A research by Cannaby (2018) also showed same results, where reputation can become primary concern for anyone who is looking to apply for a job. Job seekers will be more attracted to financial institution with good reputation. All those results shows that company reputetion is a 
significant contributor to intention to apply. Herbik et al., (1994) explained that company reputation is a way of appreciation acquired by financial instituion for their superior advantages. These advantages may differ from one company to another. In Bank Syariah Mandiri, one of such advantage is the opportunity to continuously improve itself to better fulfill the needs of their customers.

In Islamic view, fulfilling something that is entrusted to oneself (amanah), whether it is a duty or a promise, is considered a good deed. While doing the exact opposite, khianat, is strictly prohibited. This matter is explained in AlQuran surah An-Nisa verse number 58: "Indeed, Allah commands you to render trusts to whom they are due and when you judge between people to judge with justice. Excellent is that which Allah instructs you. Indeed, Allah is ever Hearing and Seeing". (QS. An-Nisa: 58)

Based on above verse, it can be concluded that Bank Syariah Mandiri, as a financial instituion, is operated with trust (amanah), which is proved by the highest loading factor of 16,862 on the indicator of financial performance. This result shows that Bank Syariah Mandiri is being wellmanaged, worthy of trust, and capable to provide a low-risk investment. With those characteristics, potential employees will perceive it as a good choice as a place for work.

\section{The Effect of Website Recruitment on Intention to Apply}

Path analysis inner model for employer branding (X1) significantly affect intention to apply (Y), which is shown by negative coefficient of -0.312 with $p$-value of 0.000 . With that result, the third hypothesis is accepted, because p-values is lower than 0.050 . This indicates that the effect of website recruitment on intention to apply on Bank Syariah Mandiri is significant negative. It is suspected that the cause of this negative correlation is an large amount of easily accessible recruitment information for the potential employees to see, which cause them to switch from one website to another at ease. On the other hand, website recruitment that was used by Bank Syariah Mandiri has a rather simple design, which contribute to less attention by potential employees. Based on theory by Cober et al. (2004), the design of a website used for recruitment is one of the main concern for job seekers. The appearance of a recruitment site can make it more appealing to those who sees it. In the case of Bank Syariah Mandiri, this site is the first thing that job seekers is most likely to see. Therefore, gives away the first impression whether or not the company is worth working for.

Based on this research, it is evident that website recruitment has a significant impact on intention to apply. This result supports previous research by Wasis (2018), which stated that website recruitment had a significant impact on intention to apply. Few other pas researches also support finding in this study (Allen et al., 2013; 
Walker et al., 2011; Williamson, 2010; Matthias and Rudhiger, 2014.)

Findings in this research indicates that website recruitment is capable to contribute significantly to intention to apply, even when the results are negative. Because of this, Bank Syariah Mandiri needs to pay close attention to their website, be it about the appearance or the ease of use. With an appealing site and easy-to-use features provided, it is possible that their website recruitment will give a significant positive effect to intention to apply. Cappeli (2001) explained that a website is the main address used by a company to attract more job seekers. For Bank Syariah Mandiri, providing a website recruitment means that they must also provide complete and necessary information about themselves, while also explaining about job description and benefits. Compared to traditional recruitment, website recruitment by Bank Syariah Mandiri is rather easy to access by job seekers and also provide many informations regarding the company itself. Because of this, website recruitment can become a valuable tool for Bank Syariah Mandiri, provided that it is managed correctly. All kind of informations will affect the final decision of potential employees, because from such information, they will also learn about the nature of the company itself.

In Islamic view, any kind of information must be provided clearly and completely. Withhelding information that can cause harm is not advised. It is as stated by the hadith from the Prophet Muhammad SAW, where he said:

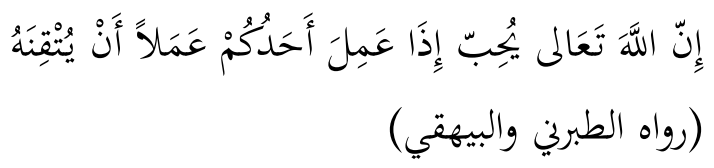

"Indeed, Allah loves those who do their jobs with Itqon (precise, organized, unambiguous, and thorough)(Thabrani)

Prophet Muhammad SAW advised to choose between workers in the best way possible, so that there will be no mistakes and injustices in the process of recruitment. He said:

$$
\text { إِذَا أُسْنِدَ الْأَمْرُ إِلَى غَعْرِ أَهْلِهِ فَانْتَظْرْ السَّاعَةَ }
$$
"Leave a job to those who do not have the expertise and you shall only wait for desctruction" (Bukhari)

Based on above hadith it can be concluded that providing information should be done as detail as possible, so any kind of misinformation in employee recruitment can be avoided. On the other hand, providing a detailed information will also makes it easier for the company to find the right man for the job. If website recruitment is developed to become more viable option by making it more informative and easy to use, then a positive outcome can be expected from such process, because intention to apply will also rise significantly.

\section{v. CONCLUSION}

From findings and discussion of this research, it can be concluded that there is a positive and significant effect from employer branding to intention to apply in Bank Syariah Mandiri. Which means, if employer branding is managed well, then 
job seeker's intention to apply to the company will rise. It showed that employer branding can affect the final decision for many undergraduate students from state universities in Malang City to apply for a job in Bank Syariah Mandiri. There is a significant positive effect from company reputation towards intention to apply. This means that a good repuattion built by company will make students from state universities in Malang City to apply for a job in Bank Syariah Mandiri. It is also found that there is a negative significant effect from website recruitment towards intention to apply. Which means, if there are so many online recruitment are easily accessible to potential workforce, then it will reduce the intention of job seekers to apply to a particular company. Because of this, it is evident that website recruitment can affect students from state universities in Malang City to apply for a job in Bank Syariah Mandiri.

\section{REFERENCES}

Allen, David G. (2007). Web-based recruitment: Effects of information, organizational brand, and attitudes toward a web site on applicant attraction. Journal of Applied Psychology, 92(6), 1696-1708. DOI: https://doi.apa.org/doi/10.1037/00 21-9010.92.6.1696

Arasanmi, N Christopher. (2018). Employer branding: Perceived organisational support and employee retention the mediating role of organisational commitment. Journal Industrial and Commercial Training, $51(3), \quad$ 174-183. DOI: https://doi.org/10.1108/ICT-10-20180086

Barber, A.E. (1998). Recruiting employees. Thousand Oaks, CA: Sage Publications.
Cable, D. and Turban, D. (2001). Establishing the dimensions, sources and value of job seekers' employer knowledge during recruitment. Research in Personnel and Human Resources Management, 20, 115163.

Chapman, S. Maydren. (2005). Applicant attraction to organizations and job choice: A meta-analytic review of the correlates of recruiting outcomes. Journal of Applied Phsycology, 90(5), 928-944.

Cable, Daniel.M \& Turban, Daniel.B. (2003). The value of organizational reputation in the recruitment context: A brand-equity perspective. Journal of Applied Social Psychology, 33(11), 2244$2266 . \quad$ DOI: https://doi.org/10.1111/j.1559-

1816.2003.tb01883.x

Cable, Daniel. M, Turban, Daniel. B. (2003). Firm reputation and aplicant pool characteristic. Journal of Organizational Behavior, 24 (6), 733751.

DOI: https://doi.org/10.1002/job.215

Cober, T. Richard. (2004). Recruitment on the net: How do organizational web site characteristics influence applicant attraction?. Journal of Management, 30(5), 623-646.

Cooper, D. R., Schindler, P. S. (2011), Business research methods 111 th ed.) New York: McGraw-Hill/Irwin.

Departemen Agama RI. Al-Qur'an dan terjemahannya. Bandung: CV Penerbit J-Art.

Davis,K.Y. (2017). Integrating job search behavior into work study knowledge and job seekers employers attractiveness organization. The International Journal of Human Resource Management, 30(9), 1448-1476.

Fridantara, Angga Swasdita dan Muafi. (2018). Pengaruh daya tarik perusahaan dan e-recruitment terhadap keinginan melamar pekerjaan pada calon karyawan generasi $Y$ : Peran reputasi perusahaan sebagai variabel mediasi. Tesis tidak dipublikasikan. Yogyakarta: Universitas Islam Indonesia. 
Fajrina, Rany Sherly. (2012). Pengaruh reputasi perusahaan dan komunikasi perusahaan word of mouth terhadap keputusan melamar kerja. Tesis tidak dipublikasikan. Depok: Fakultas IImu Sosial dan IImu Politik, Universitas Indonesia.

Ferizal, I. (2016). Journey to be employer of choice. Jakarta: PT Gramedia Pustaka Utama.

Fombrun, S.M. (1996). Reputation building and corporate strategy. Academy of Management Journal, 33(2), 233-258.

https://www.Mandiri.co.id diakses pada tanggal 25 Desember 2019

Kabst, M. B., \& Rudiger, Matthias (2014). The effectiveness of recruitment advertisement and recruitment website indirect and intercartive effect on aplicant atraction. Human Resource Management, 53(3), 353-378.

Lievens, F., \& Highhouse, S. (2003). The relation of instrumental and symbolic attributes to a company's attractiveness as a employer. Personnel Pysychology, 56(1), 75102. DOI: https://doi.org/10.1111/j.17446570.2003.tb00144.x

Permadi, Komang Dede .(2015). Pengaruh reputasi, kompensasi, dan lingkungan kerja terhadap minat melamar kerja oleh mahasiswa Universitas Udayana. E-Jurnal Manajemen Unud, 4(10), 32563286.

Richard, Chunyan Xie. (2012). The impact of reputation and identity congruence on employer brand attractiveness. Journal Marketing
Intelligence \& Planning, 33(2), 124146.

Sharma, Rucika. (2018). Employer brand and its unexplored impact on intent to join. Intenational Journal of Organizational Analysis, 26(3), 536-566.

DOI: https://doi.org/10.1108/IJOA-112017-1280

Sumardana,Octavianus. (2014). Pengaruh reputasi perusahaan, deskripsi pekerjaan, dan kompensasi yang ditawarkan perusahaan terhadap minat melamar pekerjaan. Jurnal Buletin Studi Ekonomi, 19(2), 184192.

Sugiyono. (2013). Metode penelitian bisnis. Bandung: CV. Alfabet.

Santiago, J. (2019). The relationship between brand attractiveness and the intent to apply for a job: A millenials' perspective. European Journal of Management and Bussines Economics, 28(2), 142-157. DOI: https://doi.org/10.1 108/EJMBE12-2018-0136

Williamson, J.E., Lepak, D., dan Sarma, A. (2010). Firm reputation, recruitment web site and attracting applicants. Journal of Human Resource Management, 49(4), 669-687.

Walker, J. H., Feild, S. H., Giles, F. (2009). Displaying employee testimonials on recruitment web sites: Effects of communication media, employee race, and job seeker race on organizational attraction and information credibility. Journal of Applied Psychology, 94(5), 1354$1364 . \quad$ DOl: https://psycnet.apa.org/doi/10.103 7/a0014964 